\title{
Nostalgia za komunizmem w polskiej wersji
}

Weronika Woźnicka

Instytut Filologii Słowiańskiej, Uniwersytet Śląski w Katowicach

Institute of Slavic Philology, University of Silesia in Katowice

weronikawoznicka@gmail.com

Za komuny było lepiej... To określenie słyszał w Polsce chyba każdy bez względu na wiek. Wśród młodszego pokolenia można zauważyć nostalgię za komunizmem, która przybiera różne formy: restauracje, gadżety (kubki, poduszki itp.), imprezy. Wszystko to w stylu PRL-u. Głównym celem artykułu jest pokazanie, w jaki sposób ludzie młodzi, głównie studenci, którzy nie doświadczyli rzeczywistości komunistycznej Polski, sięgają po symbole okresu PRL-u. Autorka artykułu przeprowadziła również ankietę, której celem było zapytanie osób, które żyły w czasach komuny, co o niej myślą, a także jaki jest według nich powód tego, że młodzi ludzie tak chętnie otaczają się przedmiotami, przypominającymi czasy PRL-u.

Słowa kluczowe: PRL, nostalgia, komunizm, gadżety w stylu PRL-u, ankieta o PRL-u

Nostalgia for Communism - the Polish Version

It was better when there was communism... This sentence has been heard by almost everybody in Poland no matter how old they are. Among the younger generation, it can be seen that nostalgia for communism has different forms: restaurants, gadgets (cups, pillows and others). Everything in PRL style. The main goal of the article is to show how young people, mostly students that 
did not suffer Polish communism, like to use PRL symbols. The author also conducted a survey of which the main goal was to ask the people who lived through the years of communism what they were thinking about communism and what, according to them, was the reason that young people like to surround themselves with objects reminding them of the PRL era.

Key words: PRL, nostalgia, communism, gadgets in PRL style, survey about PRL

Artykuł poświęcony jest nostalgii za komunizmem. Komunizm to pojęcie, o którym każdy słyszał, jednak nie wszyscy wiedzą, czym on jest, jak wygląda/ł, jakie były/są jego wyznaczniki bądź cechy charakterystyczne. Dla lepszego oglądu sytuacji przytoczone zostaną dwie definicje, znajdujące się w internetowym słowniku języka polskiego (www.sjp.pwn.pl). Pierwsza definicja mówi, że komunizm to «ideologia i doktryna społeczna postulująca zbudowanie społeczeństwa bezklasowego, opartego na społecznej własności środków produkcji i równym podziale dóbr». Druga definicja jest bardziej konkretna i wydaje się być bliższa ludziom, szczególnie z krajów, w których komunizm istniał. Brzmi ona następująco: «ustrój totalitarny realizowany w ZSRR, narzucony krajom Europy Środkowej i Wschodniej po II wojnie światowej, oparty na monopolu władzy skupionej w rękach jednej partii». Reasumując, komunizm jest ustrojem, który ma na celu stworzenie społeczeństwa bezklasowego, w którym każdy ma być traktowany tak samo. Wizja nieco utopijna. A jaka była, czy też jest, rzeczywistość? Każdy zna historię na tyle, że jest w stanie odpowiedzieć na to pytanie. Jednak najlepszym źródłem informacji są ludzie, którzy mieli bezpośrednio do czynienia z tym ustrojem, czyli urodzili się, wychowywali i żyli w tym okresie. Takich osób warto zapytać, jak było za komuny. Jednak, jak zawsze bywa w takich sytuacjach, ile osób tyle opinii. Czasami są one sprzeczne, jednak w większości się pokrywają.

Czasy komunizmu w Polsce przypadają na lata 1944-1989. Wydarzeniem, które zapoczątkowało władzę komunistów w Polsce jest utworzenie 21 lipca 1944 Polskiego Komitetu Wyzwolenia Narodowego (PKWN), będącego tymczasowym organem władzy wykonawczej na obszarach wyzwalanych spod okupacji. Wydarzeniem, które doprowadziło do zmian ustrojowych są obrady Okrągłego Stołu, prowadzone od 6 lutego do 5 kwietnia 1989, w wyniku których doszło do pierwszych, częściowo wolnych wyborów w Polsce po II wojnie światowej. 
Okres ponad czterdziestu lat komunizmu w Polsce jest często nazywany mianem „czasy PRL-u”. PRL to skrót od nazwy państwa polskiego, której pełna forma brzmiała Polska Rzeczpospolita Ludowa. Państwo funkcjonowało pod taką nazwą w latach 1952-1989. Określenie „czasy PRL-u” lub po prostu „PRL”, czy ogólnie mówiąc „epoka PRL-u” nawiązuje do czasów komunistycznych, a więc jest przez innych stosowana jako nazwa dla ówczesnego ustroju państwowego. Można ją traktować jako synonim dla hasła „czasy komunistyczne”. Mówiąc prościej, gdy ktoś powie „w PRL-u” oznacza to „za komuny”.

Ponad 25 lat temu Polska pożegnała się z ustrojem komunistycznym. Od tego czasu, a dokładnie od 1989, jest to kraj demokratyczny. Mimo to w ostatnich latach można w Polsce zauważyć swojego rodzaju tęsknotę, czy też nostalgię za dawnymi czasami. Interesujące jest, że tendencja do wspominania komunizmu pojawia się u osób młodych, które nie mają możliwości pamiętać tamtych lat ze względu na to, że po prostu urodziły się albo w latach 8o-tych, kiedy to powoli dochodziło do zmian, albo urodziły się już w wolnej Polsce. Tęsknota ta przejawia się w różnych dziedzinach życia, jak np. w turystyce, kulinariach, rozrywce, i przybiera rozmaite formy.

Spacerując ulicami polskich miast, szczególnie tych większych, np. Warszawy, można napotkać na lokale, przypominające swoim wyglądem te $z$ okresu PRL-u. Do dawnych czasów nawiązują restauracje i, przede wszystkim, bary. Ich wystrój jest wzorowany na wyglądzie miejsc z okresu komunizmu. Na ścianach porozwieszane są plakaty z hasłami typowymi dla tamtych czasów, zdjęcia pochodzące $z$ PRL-u, a także gazety z tamtego okresu, które mają przypominać tapetę. Dla młodych ludzi, a także dla turystów, taki wygląd jest bardzo atrakcyjny. Nie tylko oprawa jest w stylu peerelowskim, także kelnerzy są ubrani odpowiednio do motywu przewodniego. Często również menu nawiązuje do tego z czasów komunistycznych, głównie jednak dotyczy to przekąsek do napojów alkoholowych. Warto dodać, że bary w takim stylu są atrakcyjnie nie tylko ze względu na wygląd, ale także ze względu na cenę, gdyż piwo w takim miejscu kosztuje 4 złote, czyli ok. 1 euro. Nie da się ukryć, że tego typu bary są bardzo oblegane przez młodych ludzi, dlatego jeśli ktoś chciałby spędzić piątkowy wieczór w jednym z takich lokali w Katowicach, to należy się do niego wybrać odpowiednio wcześniej, aby znaleźć wolne miejsce. Ciekawostką jest, że jedną z restauracji w stylu PRL-u odwiedził podczas swojego pobytu w Polsce Bruce Willis. Szczęśliwym lokalem była Oberża pod Czerwonym Wieprzem w Warszawie. 
Dużą popularnością $\mathrm{w}$ ostatnim czasie cieszą się również różnego rodzaju imprezy organizowane w stylu PRL-u. Sylwester, Andrzejki, bal karnawałowy. To tylko trzy $\mathrm{z}$ wielu zabaw, które można urządzić według dawnych standardów. Wystrój sali zawiera motywy z PRL-u (mogą być podobne do tych, jakie znajdują się w restauracjach i barach, o których wspomniano w powyższym akapicie). Przeważnie uczestnicy takich wydarzeń muszą ubrać się odpowiednio do tamtego okresu. Organizatorzy dbają również o oprawę muzyczną. Na większości tego typu imprezach obowiązują piosenki, które były popularne w latach 60., 70. i 80. Jeśli chodzi o jedzenie, to czasami również ono w jakiś sposób odpowiada standardom komunistycznym. Dotyczy to jednak bardziej przekąsek niż dań głównych. Wśród gości imprez w stylu PRL-u częściej są ludzie młodzi, którzy nie żyli lub nie pamiętają tamtych czasów. Pokazuje to, że czasy komunizmu mają w sobie coś, co przyciąga młodych i sprawia, że bardzo chętnie biorą udział w tego typu zabawach.

W sklepach można znaleźć wiele gadżetów, które nawiązują do motywów peerelowskich. Kupić można praktycznie wszystko: kubki, magnesy, poduszki, koszulki i inne. Wszystkie te rzeczy zawierają coś charakterystycznego dla tamtych czasów, np. plakaty, zdjęcia, typowe hasła. Wpisując w wyszukiwarce internetowej hasło: "gadżety z PRL-u” wyskoczą adresy stron sklepów internetowych, które oferują właśnie takie przedmioty. Zaskakująca jest liczba tych sklepów. Okazuje się, że nie jest ich mało, a zakup takich peerelowskich pamiątek reklamują jako dobry prezent na prawie każdą okazję (nawet ślub).

Mówiąc o nostalgii za czasami PRL-u, czy też komunizmu, nie można pominąć instytucji, której zadaniem jest kolekcjonowanie różnego rodzaju zbiorów i udostępnianie ich publiczności. Mowa o muzeum. W Polsce powstają prywatne muzea, o niewielkiej powierzchni, które gromadzą rzeczy z czasów komunistycznych. Jednym z takich miejsc jest „Czar PRL”, muzeum mieszczące się w dawnej fabryce PZO przy ul. Mińskiej 25 w Warszawie. Całość mieści się w starym mieszkaniu, które zostało umeblowane i wyposażone zgodnie z panującą modą minionej epoki. Oprócz zwiedzania lokalu właściciele oferują także zwiedzanie Warszawy, m.in. proponują wycieczkę śladami PRL-u. Jednym z większych muzeów prezentujących historię Polski Ludowej jest Muzeum PRL-u w Rudzie Śląskiej, prowadzone przez Fundację Minionej Epoki. W placówce prezentowane są głównie wnętrza mieszkań oraz przedmioty codziennego użytku, pochodzące z okresu od 1945-1989. W jednym z pomieszczeń zorganizowano 
kino, w którym wyświetlane są kroniki filmowe i peerelowskie Dobranocki. Istnieje również ekspozycja plenerowa, która zawiera zbiory motoryzacyjne tamtego okresu, np. samochód FSO Warszawa, Moskwicz 400 i inne. Warte uwagi jest także Muzeum PRL-u w Krakowie. Instytucja ta jest stosunkowo młoda, gdyż założona została w styczniu 2013 roku. Najciekawsze jest jednak to, że zbiory muzealne można obejrzeć w Internecie. Placówka prowadzi bowiem katalog online, który jest ciągle uzupełniany i ulepszany.

Warto wspomnieć również o ciekawym projekcie naukowo-badawczym. Para dziennikarzy, Izabela Meyza i Witold Szabłowski, zdecydowała na pół roku przenieś się do PRL-u. Na przenosiny wybrali rok 1981, jak tego dokonali? Znaleźli mieszkanie, które zachowało meble i akcesoria z okresu PRL-u. Sami dziennikarze postanowili zrezygnować z komórek, Internetu i innych luksusów, które oferuje XXI wiek. Również poprzez swój wygląd i zachowanie postanowili dopasować się do minionej epoki, tzn. nosili ubrania pamiętające lata 8o., zmienili swój wygląd zewnętrzny, czyli uczesanie, na takie, które było modne w tamtych czasach. Próbowali również stać w długich kolejkach, kupować na kartki, gotować według przepisów polecanych przez „Przyjaciółkę”, a po Warszawie chcieli przemieszczać się legendarnym fiatem 126p. Wszystko to po to, żeby przekonać się na własnej skórze, czym różni się współczesne życie od tego, w którym żyli ich rodzice. Jakie wyciągnęli wnioski i czy wytrwali w swoim eksperymencie, tego można się dowiedzieć czytając ich książkę Nasz mały PRL. Pół roku w M-3 $z$ trwała, wąsami i maluchem.

Jak już wspomniano na początku artykułu, w Polsce coraz popularniejsze staje się wspominanie komunizmu, szczególnie przez osoby młode. Zastanawia fakt, dlaczego to właśnie ludzie młodzi najchętniej kupują gadżety wyglądające jak te $\mathrm{z}$ dawnych czasów. Czy jest to jakiś rodzaj mody, ironii, a może jeszcze coś innego? Autorka niniejszego artykułu postanowiła zapytać osoby, które żyły w czasach komuny, co o niej myślą, a także jaki jest według nich powód tego, że młodzi ludzie tak chętnie otaczają się przedmiotami, przypominającymi czasy PRL-u.

Ankieta, zatytułowana Za komuny było lepiej (?), składała się z 4 pytań i była w pełni anonimowa. Wszystkie pytania $\mathrm{z}$ wyjątkiem pierwszego miały formę otwartą i brzmiały następująco:

1. Czy żył/a Pan/i w czasach PRL (urodzeni do roku 1980)? - odpowiedź tylko „tak” lub „nie”.

2. Czy podziela Pan/i opinię, że „Za komuny było lepiej”? Jeżeli tak, to co według Pana/i było za „komuny” lepsze? - pytanie otwarte. 
3. Jaki jest według Pana/i powód tęsknoty za czasami komunizmu, szczególnie wśród osób, które nie wychowywały się w tym okresie? - pytanie otwarte.

4. Czy chciałby/aby Pan/i, żeby coś z tamtych czasów wróciło? Jeżeli tak, to co? - pytanie otwarte.

Ankieta była dostępna na stronie internetowej: https://docs.google. com/forms/d/1OjWuc2lvS33aLtg 3 GTiKGdfeWP-K6BSjl8CQSxup74k/ viewform?edit_requested=true [data dostępu: 05.11.2016]. W ankiecie wzięło udział 31 osób. Analizując uzyskane odpowiedzi można powiedzieć, że znaczna większość osób, które podzieliły się swoją opinią, to osoby znające czasy PRL-u, a więc takie, które w tym okresie żyły, doświadczyły jego specyfiki. Grupę docelową stanowili ludzie, którzy urodzili się do 1980 roku. O tym, że ankietowani spełnili założone kryteria, świadczą odpowiedzi udzielone na pytanie pierwsze.

Pytanie pierwsze miało, jak już wspomniano, formę zamkniętą. Ankietowani mieli do wyboru tylko dwie odpowiedzi: „tak” lub „nie”. Celem tego pytania było rozeznanie, ile osób urodziło się i wychowywało w czasach komunistycznych. Jednak, o czym pisano na początku artykułu, komunizm w Polsce datuje się na okres od 1944 do 1989, a pytanie ograniczono do roku 1980. Decyzja taka była spowodowana tym, że osoby, które urodziły się $\mathrm{w}$ roku 1980 pamiętają $\mathrm{z}$ pewnością więcej z ostatnich lat PRL-u, gdyż miały wtedy 9 lat, niż osoby, które urodziły się na przykład w roku 1985. Spośród 31 uczestników ankiety tylko 4 osoby, odpowiedziały przecząco na pytanie nr 1, co może oznaczać, że urodziły się w latach 80. albo już po 1989 roku. Jednak, mimo odpowiedzi „nie”, 3 z 4 osób udzieliły odpowiedzi na kolejne pytania. W związku z tym należy powiedzieć, że znaczna większość, 27 z 31 osób, żyła w czasach peerelowskich, a więc stanowiła grupę docelową, która była założeniem autorki artykułu podczas tworzenia formularza.

„Za komuny było lepiej”. Zdanie to brzmi dziwnie, można by nawet powiedzieć, że trochę absurdalnie, a jednak, jak można przeczytać w jednym z esejów polskiego dziennikarza, „Ze świecą szukać Polaka, który jest wolny od mówienia podobnych głupot” (Smoleński 2002). Faktycznie, stwierdzenie, że w czasach komunistycznych było lepiej słyszał prawdopodobnie każdy bez względu na wiek i w różnych sytuacjach życiowych. $Z$ tego powodu drugie pytanie ankiety nawiązywało do opinii, że w czasach komunistycznych było lepiej. Ankietowani mieli odpowiedzieć, czy zgadzają się z 
tym sformułowaniem. Dodatkowo, jeśli potwierdzają, że „Za komuny było lepiej", poproszono ich o napisanie, co według nich było wtedy lepsze.

Znaczna większość osób udzieliła przeczącej odpowiedzi na pytanie numer 2. Wśród 30 osób, które odpowiadały na wszystkie pytania, tylko dwóch ankietowanych zgodziło się z opinią, że w tamtym okresie było lepiej. Według tej dwójki w czasach komunistycznych pozytywnym aspektem było to, że wśród społeczeństwa była większa równość, ludzie bardziej cieszyli się z każdej zdobytej bądź kupionej rzeczy, było więcej możliwości znalezienia pracy, ludzie byli dla siebie milsi, a także lepiej przeżywano święta - dało się odczuć atmosferę świąt, gdyż wtedy były w domu rzeczy niedostępne w ciągu roku (np. pomarańcze). Dwie inne osoby stwierdziły, że zarówno zgadzają się, jak i nie zgadzają z opinią, iż „za komuny było lepiej”. Jako plusy tamtego okresu wymieniają (znowu) większy szacunek do posiadanych rzeczy, lepszą opiekę socjalną, darmową służbę zdrowia, opiekę dentystyczną w szkole i przede wszystkim - lepsze kontakty międzyludzkie, co skutkowało bezinteresowną pomocą. Minusami dla tych osób były, charakterystyczne dla tego okresu, kolejki, problem z dostępnością towarów w sklepie oraz zamknięcie Polski na nowinki z Zachodu. Niektórzy ankietowani nie udzieli odpowiedzi „tak” lub „nie”. Można tylko się domyślać, że raczej nie zgadzają się z opinią, iż w okresie PRL-u żyło się lepiej. Ciekawe jest, że mimo to, iż ludzie nie wspominają tego okresu najlepiej, większość jednak napisała, co było wtedy lepsze. Odpowiedzi były wyrażone w różny sposób, jednak w dużej mierze się pokrywały. $U$ ankietowanych powtarzały się przede wszystkim dwie opinie:

1) W tamtym okresie było mniejsze bezrobocie, ponieważ każdy kto chciał pracować miał zatrudnienie.

2) Relacje międzyludzkie były lepsze niż teraz.

Podsumowując, mimo, że większość osób twierdzi, iż zdanie „za komuny było lepiej” jest nieprawdziwe, to jednak duża liczba ankietowanych napisała, co uznaje za plusy ówczesnego systemu. Oznacza to, że jednak współczesne czasy nie są idealne we wszystkich kwestiach organizacji życia ludzkiego.

Tęsknota (czy też nostalgia) to «uczucie żalu wywołane rozłąką z kimś, brakiem lub utratą kogoś albo czegoś». Jak już wspomniano, w Polsce można znaleźć różne formy tęsknoty za czasami komunizmu. Przedmiotami o tematyce peerelowskiej otaczają się głównie ludzie młodzi, którzy w tamtym okresie nie żyli lub po prostu go nie pamiętają. Dlaczego ludzie w ogó- 
le tęsknią za PRL-em? Uczestnicy ankiety zostali w trzecim pytaniu poproszeni o napisanie powodu, dlaczego osoby nieznające komunizmu przejawiają jakiś rodzaj nostalgii za tamtymi czasami.

Wśród 30 odpowiedzi tylko jedna brzmi „nie ma”. Pozostałe osoby albo nie wiedzą, skąd nagle takie zainteresowanie komunizmem wśród młodych ludzi ( 3 osoby), albo stwierdzają, że ktoś, kto nie żył w tym okresie nie może za nim tęsknić (1 osoba), albo wymieniają powody, które są różne, jednak, tak jak w przypadku pytania drugiego, bardzo dużo $\mathrm{z}$ nich jest sformułowanych w inny sposób, ale przedstawiają ten sam pogląd. Ankietowani udzielali odpowiedzi typu: brak bezrobocia, większa równość społeczeństwa, poczucie większego wsparcia ze strony państwa. Można jednak wyróżnić trzy najczęściej powtarzające się opinie:

1) Młodzi tęsknią, ponieważ słyszą wspomnienia, sentyment rodziców i dziadków.

2) Komunizm znają tylko $\mathrm{z}$ filmów, a konkretnie komedii Stanisława Barei, który w swoich produkcjach przedstawiał absurdy komunizmu i śmiał się z ówczesnego systemu.

3) Ludzie zapominają o dawnych czasach, idealizują przeszłość.

Okazuje się, że można tęsknić nawet za ciężkimi czasami i tą tęsknotą zarażać innych. Podsumowaniem do pytania nr 3 mogą być słowa cytowanego już wcześniej polskiego dziennikarza, który w swoim eseju stwier$\mathrm{dza}, \dot{z} e$ «na tym polega niezależny od ustroju defekt człowieczej pamięci, że to, co było kiedyś, niemal zawsze wydaje się lepsze od tego, co jest dziś» (Smoleński 2002).

Człowiek przeważnie chce, żeby wróciło coś z czasów jego młodości. Mogą to być różnego rodzaju rzeczy, np. ubrania, muzyka, sposób życia i inne. Dlatego też ostatnie, czwarte pytanie ankiety dotyczyło właśnie powrotów. Zapytano, czy jest coś, co ankietowany chciałby, aby powróciło z okresu PRL-u i jeśli jest, to co.

Spośród osób, które udzielały odpowiedzi, tylko 5 zdecydowało, że nie chciałoby, aby coś powróciło z okresu komunistycznego do dzisiejszych czasów. Pozostali ankietowani wymieniali przynajmniej jedną rzecz, a odpowiedzi w większości się nie pokrywały, jednak znaczna większość nawiązywała do odpowiedzi udzielonych na poprzednie pytania. W związku z tym część osób stwierdziła, że powinien dalej istnieć obowiązek pracy bądź dostępność zatrudnienia dla wszystkich, którzy chcą pracować, a także ludzie powinni okazywać większy szacunek rodzicom, nauczycie- 
lom oraz bardziej doceniać to, co posiadają. Wymieniano również opiekę socjalną, powszechną opiekę medyczną, zakłady przemysłowe, żłobki i przedszkola dostępne dla wszystkich, darmowe mieszkania zakładowe i inne. Spora część osób odpowiadała jednak, że najbardziej by chciała, aby powróciła bliskość i życzliwość ludzi, poczucie wspólnoty, więcej czasu na życie rodzinne, co można połączyć w jedno i nazwać lepszymi kontaktami międzyludzkimi.

W dobie komputerów, telefonów, różnego rodzaju komunikatorów, a więc w okresie, kiedy teoretycznie kontakt $\mathrm{z}$ drugą osobą jest ułatwiony, ludzie chcą, aby powróciły te relacje międzyludzkie z okresu PRL-u. Komunistyczne, to znaczy jakie? To znaczy, że ludzie byli sobie bliżsi, nie traktowali innych $\mathrm{z}$ góry, ponieważ istniała większa równość w społeczeństwie. Pomagali sobie bezinteresownie i nie potrzebowali specjalnych urządzeń elektronicznych ani aplikacji internetowych, aby umówić się z kimś na spotkanie lub kogoś odwiedzić. Można powiedzieć, że współczesność odebrała większości osobom zdolność nawiązywania kontaktów, utrzymywania bliskich relacji. Duża liczba ludzi nie potrafi w dzisiejszych czasach przyjść do kogoś bez uprzedniego powiadomienia. Kontakty międzyludzkie straciły charakter spontaniczny, teraz muszą być uporządkowane i zgodne z jakimś założonym planem.

Analizując wyniki ankiety można powiedzieć, że to właśnie lepsze stosunki międzyludzkie są powodem nostalgii za czasami socjalistycznymi. Młodzi ludzie mogli zasłyszeć sentyment od rodziców lub dziadków, jak to wyglądało dawniej. Również para dziennikarzy, o których wspominano wcześniej, wyciągnęła następujące wnioski ze swojego eksperymentu: «Lata osiemdziesiąte, z całą swą topornością, to czas solidarności, czas wspaniałej, międzyludzkiej chemii, czas, gdy jedni drugich ciężary nosiliśmy» (Meyza i Szabłowski 2012). Nie można jednak wykluczyć tego, że Polskę ogarnęła po prostu zwyczajna moda na peerelowskie gadżety i lokale, a jak to $\mathrm{z}$ modą bywa, młodzi ludzie chcą być na czasie i żyć zgodnie z panującymi trendami. Wydaje się, że można jednak połączyć tęsknotę za komunizmem i nowe kierunki w modzie, o czym wspomina doktor Włodzimierz Pessel: «Wraz z tęsknotą za komuną pojawiły się w Polsce grupy młodych ludzi, którzy właśnie takich przedmiotów szukają. Interesują ich meble vintage, stare książki, płyty winylowe. Niektórzy z nich urządzają mieszkania sprzętami znalezionymi na śmietnikach» (Meyza i Szabłowski 2012).

Należałoby chyba jednak połączyć tęsknotę i modę, gdyż moda vintage w jakiś sposób nawiązuje do nostalgii za starym. Nie zmienia to jed- 
nak faktu, że te lepsze kontakty międzyludzkie są głównym powodem tej tęsknoty, co można wywnioskować z odpowiedzi ankietowanych, a o czym wspominają także autorzy książki Nasz mały PRL. Pół roku w M-3 z trwała, wąsami $i$ maluchem. W dzisiejszych czasach ludzie zatracili zdolność bezinteresownych kontaktów. Oczywiście nie dotyczy to wszystkich. Nie można wsadzać wszystkich ludzi do „jednego worka”, jednak zauważalne są zmiany we wzajemnych stosunkach międzyludzkich. W miejscach przypominających wyglądem lokale peerelowskie można poczuć atmosferę z tamtego okresu. W takich barach, restauracjach wszyscy są sobie bliscy bez względu na wiek, pozycję, zatrudnienie itd. Przejaw nostalgii za peerelem można by określić jako pewien sposób sprzeciwu wobec współczesnemu ciągłemu byciu w biegu, braku czasu dla innych i co najważniejsze braku czasu dla zacieśniania relacji, a jak wiadomo każdy człowiek potrzebuje mieć kogoś bliskiego, a jeśli ciągle skupia się na karierze, to trudno mu potem znaleźć taką osobę, która go w krytycznych momentach wysłucha i wesprze. Może dlatego też powstaje coraz więcej takich miejsc. Pociąg do czasów peerelowskich związany jest także z poszukiwaniem produktów, usług (np. gadżety, wycieczki), które odbiegają nieco od standardowych ofert dostępnych na rynku. Tego wzrostu zainteresowania dawnymi czasami i boomu na pamiątki i lokale z okresu PRL-u najlepiej zaznać będąc w Polsce i udając się do takiego baru. Człowiek na własnej skórze poczuje atmosferę miejsca i bliskość ludzi. Jednym słowem, doświadczy nostalgii za czasami komunizmu.

\section{Literatura}

Meyza, Izabela i Witold Szabłowski. 2012. Nasz mały PRL. Pół roku w M-3 z trwałą, wąsami i maluchem. Kraków: Wydawnictwo Znak.

Smoleński, Paweł. 2002. "Za komuny było lepiej, czyli o kłopotach wspólnej podróży nad morze«. W NOSTALGIA. Eseje o tęsknocie za komunizmem, red. Filip Modrzejewski i Monika Sznajderman, 114-129. Wołowiec: Wydawnictwo Czarne.

\section{Źródła internetowe}

Adventure Warsaw. »Muzeum PRL/Adventure Warsaw«. 2016. Adventure Warsaw. <http://adventurewarsaw.pl/muzeum-prl/>. (Data dostępu: 05.11.2016.) 
Fundacja Minionej Epoki. »Fundacja Minionej Epoki, Muzeum PRL-u«. 2016. Fundacja Minionej Epoki. <http://www.muzeumprl-u.pl/>. (Data dostępu: 05.11.2016.)

Muzeum PRL-u. »Muzeum PRL-u«. 2016. Muzeum PRL-u. <http://www.mprl. $\mathrm{pl} />$. (Data dostępu: 05.11.2016.)

Wydawnictwo Naukowe PWN. »Słownik języka polskiego PWN«. 2016. Wydawnictwo Naukowe PWN. <http://sjp.pwn.pl/>. (Data dostępu: 05.11.2016.) 